\title{
On the Role and Status of Political Construction in Promoting the Party's All-round Construction
}

\author{
Huihui Yan \\ Institute of Social and Cultural Studies \\ Macao University of Science and Technology \\ Macao, China
}

\begin{abstract}
In the report of the Nineteenth National Congress, it was pointed out that the political construction of the Party is the fundamental construction, and the importance of the political construction of the Party is self-evident. Chairman $\mathrm{Xi}$ also repeatedly emphasized that the party's political construction is the first of the party's construction, and has played an important leading role in promoting the party's construction in an all-round way. In the process of the transformation of the modernization of state governance in the new era of our country, it is of great significance to strengthen the leading position of the party's political construction in promoting the party's construction in an all-round way. Political construction is the ideological guarantee of the value level of the modernization of national governance; political construction provides the power source for the modernization of national governance from the behavioral orientation, and political construction is the technical support of the ability level of the modernization of national governance. In the construction of our country in the new period, the party's political construction is facing many practice tests. We need to actively explore the new path and direction of the standardization and practicalization of the party's political construction.
\end{abstract}

Keywords-political construction; party building; leading position; fundamentality

\section{INTRODUCTION}

The Nineteenth National Congress of the CPC has reestablished the general requirements of the Party's construction. Among them, the political construction of the Party is the most important, leading and core. The ultimate focus and foothold of other Party-building must be on the political construction. Therefore, the party's political construction is the fundamental construction of the party. In the new era, our party's political construction is facing many practical tests under the influence of new governance concepts such as openness and technology. The modernization of our governance also has higher requirements for the party's political construction.

\section{The PARTY'S POLITICAL CONSTRUCTION IS AN IMPORTANT Proposition of the Times IN MODERn State GOVERnANCE}

\section{A. Political construction is the ideological guarantee of the values of national governance modernization}

From the value orientation of the modernization of state governance in China, it is an important part of the Party's political construction to adhere to socialist ideals and values.
There are many problems facing the modernization of state governance, both internal contradictions and international challenges can't be ignored. This is also the inevitable problem and challenge in the development and construction of modernization for every country in today's era. So nowadays, to effectively promote the transformation and upgrading of the country and leapfrog development is not only a choice at the level of conceptual change and technology but also a choice at the level of road and value. In today's era, China is going out for an important period of reform and opening up and deepening reform. How to achieve more scientific and effective national governance in China must adhere to the main theme of values and actively guide our common values and social consensus. Through the norm of value level, it is a firm way of state governance and social development, and provides important ideological guarantee for the development and transformation of our country [1].

B. Political construction provides a source of power for the modernization of state governance from the perspective of behavior

In the Party's political construction, strengthening the Party's self-cultivation and discipline is its important behavior orientation, which is the party spirit commonly said in our country. Maintaining Party spirit is an important source of motive force for China's modernization construction, an important source of motive force for China to achieve a series of development and construction achievements since modern times, and an important foundation that must be adhered to in the new era. Only by strengthening the self-cultivation of Party members and standardizing their own behavior can the Party's policies be well implemented and the path of more unswerving adherence to characteristics be taken. In China's modern state governance, strengthening the party's political construction is conducive to improving the ability of Party members themselves and better serving the people in specific practical work.

\section{Political construction is the technical support for the level of national governance modernization ability}

In the process of deepening reform in our country, strengthening the Party's political construction is to provide a good and orderly environment for reform. Reform will inevitably face many problems. But the most important premise of the reform is to proceed in a peaceful, stable, positive and orderly environment, which is not only the need of 
national reform and development, but also the need of the development of a harmonious socialist society. The Party's political construction can continuously improve the cultivation and ability of Party members, and provide favorable technical and ideological support for economic development and reform [2]. In the process of reform, there will be many positive demands, which will lead to different contradictions and problems. Only by strengthening the party's political construction can the orderly development of the overall construction be guaranteed. Secondly, the party's political construction can improve the ability and accomplishment of Party members, and to a certain extent, it can ensure that the relevant policies and measures of governance are active and effective, thus achieving good results of national development and transformation. Governance of the country depends more on the norms of the legal system. In a reasonable and legal environment, it can better promote the development and operation of society and safeguard the interests of the people. The development and perfection of the legal system also require the Party to constantly strengthen its own political construction. Through improving the Party's governing quality and ability, and constantly in accordance with the specific national conditions of social development, establish and improve our laws and regulations, so that more active and orderly state governance.

\section{The Political Construction OF THE PARTy FACES MANY PRACTICAL TESTS}

\section{A. The way of diversified governance in the construction of political parties has the effect of weakening the authority of political parties}

The concept of pluralism in the governance of modern countries has already been deeply rooted in the hearts of the people. Diversification includes diversification of governance subjects, means and objectives. The development of the times requires the continuous renewal and optimization of the concept of national development and governance. The diversification of governance subjects is to give full play to the wisdom of the people and let more and more members of the social subjects participate in the management of society and the governance of the country. In the traditional way of state governance, the people have always been in a managed and dominated position. Many policies and regulations lack the participation of the masses, so it is difficult to adapt to the specific environment of social development in the specific implementation, and it is difficult to generate more identity among the people. Diversified governance mode allows the society to participate in the governance of the country, through the way of social brotherhood market consultation, so as to achieve the ultimate goal of maximizing the interests of the whole society. In the diversified state governance, the people have more voice and more appeals for their own interests. At the same time, the development of some new information technology gives people more opportunities to participate in the governance of the country, and promote the formulation and implementation of relevant policies through interaction and exchange. Although diversified governance can better adapt to the development of socialist market economy, it puts forward higher requirements for the ability of Party governance and coordination, weakens the authority of Party to a certain extent, and is not conducive to the development of socialist values as a whole. It is necessary to constantly strengthen the Party's political construction and provide an ideological guarantee for diversified governance.

\section{B. The way of open governance in the construction of political parties to eliminate the identity of people's value}

For the governance of the country and the construction of the party, the people's sense of identity is the highest affirmation, belonging and dependence on values and emotions. In recent years, the development and construction of China's political and economic make people generally have a sense of social identity. However, although social development and change, this sense of identity may change, which requires our political parties to constantly improve their own construction, better people's service, so that the construction of socialism more to meet people's demands. Under the open modern governance environment, different interests demand more scientific and effective governance of the country, and different cultural concepts will deeply affect the choice of national policies and routes. In the political construction of the Party, different viewpoints and interests need to be involved and then rise to the level of national governance, which will inevitably affect the people's sense of identity to a certain extent. Regarding some conflicting interest demands, no matter what kind of choice will eliminate the social level of identity. In addition, open governance will inevitably have a certain impact on the construction of core values and dispel the political consciousness of Party members. Therefore, to strengthen the political construction of our Party, we must pay attention to the influence of diversified governance methods [3].

\section{The way of institutional governance in the construction of political parties tests the discipline of our own party}

Compared with the traditional mode of man-made governance, modern institutionalized governance will inevitably become an important concept of governance for our country in the future, and will also be implemented in the development and construction of society. But for a long time, although our country has been constantly building the legal system and perfecting the relevant laws and regulations, which has played a very good role in social development, the overall level of institutionalization construction still needs to be improved [3]. On the one hand, it requires the relevant public officials to constantly change their concepts, regulate their own behavior through institutionalized way, so that the institutionalized construction more in line with people's interests. On the other hand, the construction of institutionalization faces many problems, including the discipline of Party members themselves, so as to prevent the situation that power is greater than the system. Only when the construction of multi-life institutionalization restricts the power effectively, can we really achieve effective governance and prevent the abuse of power, which has higher requirements for the discipline and literacy of our civil servants. 
D. The way of technical governance in the construction of political parties challenges the ability of political parties to govern

In today's information technology development process, people's way of thinking and living habits have changed a lot, network information technology has gradually penetrated into the development and governance of the country. How to effectively use Internet technology to optimize the governance of the country is a very important test for political parties. They require political parties to make corresponding adjustments and changes, not only the transformation of traditional means and methods of governance, but also the transformation of values. If information technology is well applied, it plays a very important and positive role in the development and governance of the country, can improve the decision-making and authority of political parties, and can better lead the development and change of social values [4]. Therefore, the party's political construction requires that we must do a good job in the development of information technology, so that it can better serve the development of society and the governance of the country.

\section{Strategies to StREngthen the PARTy's Political CONSTRUCTION IN PROMOTING THE LEADING POSITION IN THE PARTY'S CONSTRUCTION}

\section{A. Match the political construction of the party and the governance of the country}

Throughout the history of China's modern development, the Party has led the people to successive victories, including a series of achievements in the development and construction of contemporary China's economy and politics, which are inseparable from the Party's political construction. The development of China's modernization must be closely combined with the Party's political construction, and better promote the development and governance of the country under the guidance of the Party's political construction. Nowadays, China's economic and social development is facing new problems and challenges. Whether it is the fairness of domestic development or the prevalence of new trade protectionism in the international community, it is quite complicated and severe. It needs our country to develop more scientifically and effectively and actively respond to new problems. This requires strengthening the party's political construction to achieve the new goal of national governance and development.

\section{B. Construct the criteria for the innovation of the party's political construction system}

In the process of the Party's political construction, on the one hand, we should adhere to some principles, such as democratic centralism and some principles of obedience to the system, and even specific legal system construction, but at the same time, we should also innovate and standardize accordingly according to the new problems and environment in the process of political construction. In the process of concrete practice and development, we should give full play to the initiative of the people, care about the interests of the people, and make the party's political construction more standardized and effective. The importance of the Party's political construction is self-evident. The state has promulgated a number of laws and regulations for the political construction of the party, including work regulations, accountability regulations, and other provisions. While standardizing the system, we must also pay attention to the innovation of political construction, and create a good social atmosphere for the development and improvement of political construction, so that the political construction of the party is more scientific and effective [5]

\section{Perfect the guidance of scientific theories in the party's political construction}

In our Party's political construction, we must strengthen the inheritance and learning of Marxist theory and carry out the development and construction of the national economy under the guidance of theory. On the one hand, according to the new situation of social development, we need to use Marxist theory to explain and guide, so that scientific theory can serve the development and construction of modernization. On the other hand, in the process of political construction and social development of the Party, we should constantly optimize and develop scientific theories, so that scientific theories can better achieve the role of valuable guidance.

\section{Adhere to the political construction of the party in a diversified and open way}

Diversified opening-up is an important trend in the future development of the international community. The party's political construction is not only limited to the development within the country but also can play its role well under the background of the international environment to ensure its selfcultivation and ability. We should actively adapt to the development of the international community, integrate domestic resources, carry out the Party's political construction, strengthen the Party's political beliefs, and avoid being influenced by the peaceful evolution of Western ideas. At the same time, we should actively learn from the advanced theories and experiences of foreign countries and combine them with our national conditions to form the political construction of the Party with Chinese characteristics.

\section{CONCLUSION}

The political construction of the Party is the fundamental construction of the Party, which decides the direction and effect of the Party's construction. Strengthening the Party's political construction is a major and arduous political task. The Party's political construction plays a very important leading role in promoting the Party's construction in an all-round way, and it is also the core and focus of the Party's work, playing a very important role in the development and governance of the country. At present, the development of China's economy and politics is facing the impact of profound changes in the domestic environment. Especially in the process of economic globalization and China's economic transformation, we must thoroughly analyze the opportunities and challenges of the development of the new era, and do a good job in the party's political construction. Through the party's political construction, better regulations promote the development of the country, and through the party's political construction, we will build our 
party to be stronger and stronger, and provide a strong political guarantee for realizing the goal of "two hundred years" and the Chinese nation's great rejuvenation of the Chinese dream.

\section{REFERENCES}

[1] Feng Xiaomin. Adhere to the Problem Orientation and Earnestly Improve the Quality of Party Building [J]. Shanghai Party History and Party Building, 2019, No. 380, 5-8.

[2] Zhang Jian. The Path of Continuously Improving the Quality of Party Building in the New Era [J]. Knowledge, 2019, 34-36.
[3] Cheng Jinglin. The Construction of the Party in the New Era must be Disciplined and Strong [J]. Leadership Science Forum, 2018, 51-53.

[4] Zhang Xiaoyan. Study on the Definition Method of the Connotation Category of the Party's Political Construction-Concurrently on the Connotation, Extension, Basic Components and Logical Relationship of the Party's Political Construction[J].Journal of Yuejiang University,2018,v.10; No.57 , 7-18+144.

[5] Gong Yanbo. On the Realistic Position and Practice Path of the Party's Political Construction [J]. Party History and Bocai (Part 2), 2018, No.564, 42-43. 